\title{
Learning and Memory Enhancing Activity of Cowpea Diet Ingestion in the Morris Water Maze Task
}

\author{
Aduema $\mathrm{W}^{1 *}$ and Wariso $\mathrm{AC}^{2}$ \\ ${ }^{1}$ Department of Human Physiology, Gregory University, Nigeria \\ ${ }^{2}$ Department of Human Physiology, Abia State University, Nigeria
}

Submission: October 11, 2017; Published: November 10, 2017

*Corresponding author: Aduema W, Department of Human Physiology, Gregory University, Uturu, Abia State, Nigeria, Email: Wadioniaduema@gmail.com

\begin{abstract}
It was therefore the aim of this study to find out whether long term consumption of beans (Cowpea) diet has effects on some neurobehavioral parameters notably; learning and memory, using Swiss white mice as experimental animals. Forty (40) CD1 mice were randomly assigned into four groups, via; control, cooked beans diet $(50 \% \mathrm{w} / \mathrm{w})$, uncooked beans diet $(50 \% \mathrm{w} / \mathrm{w})$, while another set of mice was placed on serotonin precursor (5-HTP) diet $(0.2 \mathrm{mg} / 50 \mathrm{~g} \mathrm{w} / \mathrm{w})$ for thirty days. All the mice had access to clean drinking water ad libitum. Learning and memory, was investigated alongside food and water intake and body weight change. Involvement of serotonin pathway was investigated using the set of mice administered serotonin precursor for comparison with the beans diet fed mice.

Mice were tested in the Morris water maze for 8 days: 3 days of acquisition training, 3 days of reversal training, 1 day of single probe trial and 1 day for visible platform task. Learning on days $1,2 \& 3$ of acquisition training was improved in the beans and serotonin precursor diet-fed mice when compared to control $(\mathrm{p}<0.001$,respectively). The trend was similar during the reversal training, memory was improved in the beans and serotonin precursor diet-fed mice when compared to control ( $p<0.001)$.During the probe trial, the swim duration in the South-East quadrant was significantly higher for beans and serotonin precursor group compared to control $(\mathrm{p}<0.05)$. However, during the visible platform task, the swim latencies for the beans and serotonin precursor group was significantly lower compared to control. In conclusion, long term consumption of beans diet enhances learning and memory. One of the active chemicals involved in these effects following beans consumption may be serotonin. Keywords: Learning and Memory; 5-Hydroxytryptophan; Cowpea; Mice
\end{abstract}

\section{Introduction}

Common bean (Vigna unguiculata) is a dicotyledon and belongs to the pea family [1]. Beans are available as the dry mature seeds or the green immature seeds which are wrapped in pods [2]. Both types are edible. There are many varieties of dry bean classes depending on the color, shape and size. Some of the commonly consumed varieties are navy, black, kidney and pinto beans. Bean are used as staple food in Nigeria and globally [3] and are a superb source of protein, carbohydrates, dietary fiber, minerals, vitamins and many phenolic compounds [4]. Bean is a very nutritious food $[5,6]$ and has been reported to exhibit that beans have ant carcinogenic, anti-mutagenic [7]. Anti-inflammatory, anti-diabetic, hypoglycemic, depurative, cardio-protective and antioxidant effects [8].

Beans are rich in serotonin and its precursor 5-Hydroxytrytophan (5-HTP) [9]. They also contain saponins, tannins, glycosides and flavonoids [9]. A key feature of serotonins is the regulation of neurobehavioral such as mood, memory, learning, and sleeps [10]. Evidence suggest that serotonin acting as a neu rotransmitter on both neurons and muscles is able to modulate behavior in response to changing cues, to affect egg laying, pharyngeal pumping, locomotion in the roundworm Ceanorhabditis elegans (C elegans) [11]. Since beans contain serotonin and 5-HTP and chemicals that can potentially affect behavioral patterns, it may be worthwhile to investigate whether long-term consumption of beans diet can affect behavior. This is of particular interest when considering the challenges that confront human behavior and how behavioral disorders still remain a global health concern [12]. Therefore, this study explores the effect of long term consumption of beans on behavior (using mouse behavioral model).

It is likely that behavioral changes can be associated with stable foods like beans, since it contains neurotransmitters, especially serotonin and its precursor 5-Hydroxytryptophan, known to exhibit neurobehavioral actions. This study therefore, investigates the effect of beans on neurobehavioral parameters using 40 Swiss white mice. 


\section{Anatomy Physiology \& biochemistry international journal (APBIJ)}

\section{Experimental Animals}

Forty (40) adult Swiss white mice weighing between 15-30g obtained from the disease -free stock of the animal house, Department of Physiology, University of Nigeria, Nsukka were used for this research work. The animals were randomly assigned into four (4) groups of ten (10) animals per group. Each mouse in a study group was individually housed in a plastic cage with iron gauze bottom grid and a wire screen top. The animal room was adequately ventilated, and kept at room temperature and humidity of $22 \pm 30$ c and $40-70 \%$ respectively with 12 hour natural light-dark cycle.

\section{Experimental Design}

Mice were weighed using digital weight balance. Identification of animals was simply done using identification cards attached to each cage, because animals were singly housed. The mice were grouped into four: Each of these groups consisted of ten (10) mice [group 1=control, group $2=$ cooked beans, group $3=$ uncooked beans and group $4=5 \mathrm{HTP}]$. In all, forty (40) mice were used for the experiments and the experiments were run for thirty (30) days. The mice were aged between 30 and 35 days and weighed between $15 \mathrm{~g}$ and $30 \mathrm{~g}$. All the animals were clinically and andrologically examined and confirmed to be free from systemic disorders.

\section{Preparation of Powdered Beans Diet}

Ten cups of bean was bought, out of which 5 cup was cooked, air dried and grounded into powder form. The uncooked bean was milled into powder form as well. Fifty gram of powdered cooked or uncooked beans was mixed separately with $50 \mathrm{~g}$ of normal rodent chow making $50 \%(\mathrm{w} / \mathrm{w})$ of beans diet. The diet was then used to feed the test groups.

\section{Preparation of Serotonin Precursor Diet}

Serotonin precursor (5-Hydroxytryptophan) was obtained from May and Baker United Kingdom, and used for the study. From the estimation of the powdered 5-Hydroxytryptophan (serotonin precursor) content of cooked and uncooked beans according to the method of Feldman JM, Lee [13]. As modified by Mosienko et al. [14]. The serotonin precursor diet was prepared by mixing $40 \mathrm{mg}(0.04 \mathrm{~g})$ of the precursor in hundred gram $(100 \mathrm{~g})$ of the feed.0ne gram $(1 \mathrm{~g})$ of the mixture was mixed with $99 \mathrm{~g}$ of the feed. So that the amount of 5HTP added was equivalent to that contained in the beans diet? An electric blender was used to blend the mixture to form the serotonin precursor diet.

\section{Experimental Protocol for Learning and Memory}

The Morris water maze modified for mice were used [15]. The water maze was constructed using a circular rubber basin that measures $110 \mathrm{~cm}$ in diameter and $20 \mathrm{~cm}$ in depth. The pool was filled to a depth of $14 \mathrm{~cm}$ with water. The water was made opaque with the addition of liquid milk to ensure camouflage of the white escape platform. The platform was submerged by $1 \mathrm{~cm}$ of water. The water was left to stay overnight in order to achieve room temperature.

The pool was divided into four quadrants: Northwest, Northeast, Southwest and Southeast. Boundaries of these quadrants were marked on the edges of the pool with masking tape and labeled: North, South, West and East. A square solid block $(10 \mathrm{~cm}$ $x 10 \mathrm{~cm}$ ) covered with white gloves was used as the escape platform in the maze. The level of water in the pool was adjusted to $1 \mathrm{~cm}$ above or below the platform. Thus, creating a visible or invisible platform respectively. On the walls of the room were mounted several posters to act as visual cues. During testing, the room was dimly lit with sunlight passing through the window covered with curtains. The performance of the animals in the maze was measured both manually and electronically.

\section{Procedure}

Testing in the Morris Water Maze lasted for eight days. The first three days were acquisition training with the invisible platform. Day 4-6 were reversal training, again with an invisible platform. On the seventh day, a probe trail was conducted with no escape platform. On day eight, four trials were conducted using the visible platform. ACQUISITION (Platform in North West for days 1, 2, 3) During acquisition training, the water was adjusted appropriately such that the platform was covered by $1 \mathrm{~cm}$ of colored water (invisible platform). The platform was placed in the centre of the North West quadrant. Each animal received 4 trials of 60 seconds (max) per day. The starting positions of the animals were predetermined which prevented any sequence of two trials to be repeated by the same animal during any other day.

Possible start positions were at the boundaries of the quadrants (e.g. West, North, East or South).Each mouse was removed from its holding cage using a small clean $500 \mathrm{ml}$ plastic container to minimize handling stress. The animal was then placed into the water at the appropriate start position, facing the centre of the pool. The mouse was then permitted to explore the pool and to search for the hidden escape platform for 60 seconds. When the animal located the platform, the timer was stopped and the animal removed using the plastic container and placed in the holding cage. If the animal did not find the platform during the allotted time, the animal was guided onto the platform using the plastic container. Once on the platform, the mouse was permitted to visually explore its surroundings for 20 seconds, at which point it was picked up in the plastic container and returned to the appropriate holding cage.

The next mouse was then placed in the pool and the same procedure followed .Each animal completed four trials per day over 3 days, i.e.12 trials of acquisition training. REVERSAL (Platform in South East for days 4, 5, 6) Reversal training began on day 4 . The invisible platform was moved to the opposite quadrant (southeast quadrant), and the mouse again assigned to appropriate start positions. The same procedures as in acquisition 


\section{Anatomy Physiology \& biochemistry international journal (APBIJ)}

training were carried out during reversal training. Each of the animals completed four trials per day for 3 days I.e. 12 trials of reversal training. Probe (No platform, Day 7) a probe trial was conducted on day 7.At this time; there was no escape platform at all-in the maze. Each animal completed one trial of 60 seconds. Each mouse was placed in the maze from one of the four possible start positions and allowed to explore the pool. The duration in each quadrant and the frequency of entry into the North-West and South-East were noted. Visible Platform (Visible Platform at South West, Day 8) the visible platform task was conducted on day 8 . The visible platform was placed in the Southwest quadrant of the pool. The same procedures as in the acquisition and reversal training were carried out and each mouse completed four trials. During acquisition, reversal and visible platform test, the following behaviors are measured: (1) swim latency (time to find and mount the escape platform). During the probe trial, the measures recorded are

Results a) Frequency of entries into each quadrant (Northeast, Northwest, Southeast and Southwest),

b) Duration of time spent in each quadrant,

c) The number of times the mouse crosses the location of the platform during reversal training (annulus reversal crossing),

d) The number of times the mouse crosses the location of the platform during acquisition training (annulus acquisition crossing).

\section{Statistical Analysis}

Data collected were expressed a Mean \pm SEM (standard error of mean), analysis of variance (ANOVA) and the student's' test were used for analysis. "P" value less than 0.05 , was considered statistically significant.

\section{Acquisition Training}

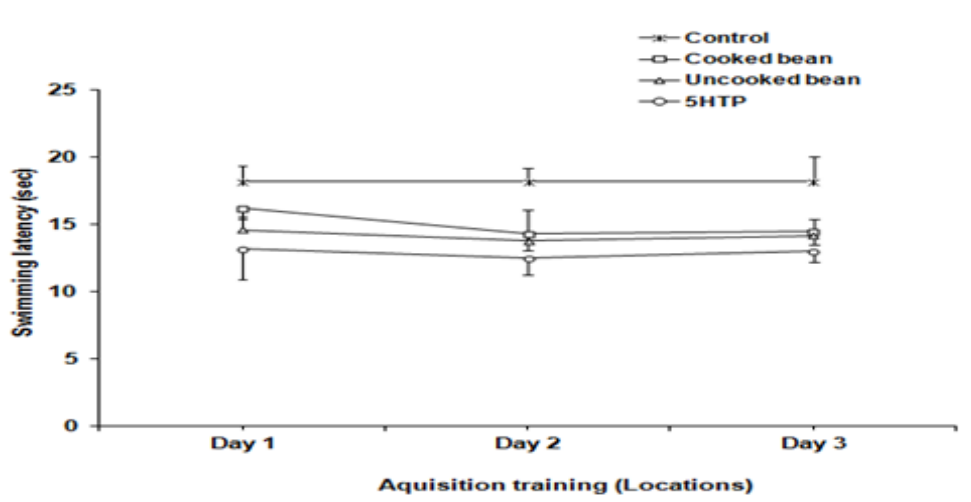

Figure 1: Swimming latency during acquisition training among the different experimental groups recorded at days 1, 2 and 3 in the Morris water maze test.

Values are expressed as mean \pm SEM, $n=10$

On day 1, the swim latencies obtained showed that mice, fed with control, cooked, uncooked beans and serotonin precursor diet scored $18.19 \pm 1.2 ; 16.23 \pm 0.8 ; 14.60 \pm$ and $13.20 \pm 2.3$ seconds respectively. In day 2 , the swim latencies were $18.18 \pm 1$; $14.30 \pm 1.2 ; 13.80 \pm 2.3$ and $12.50 \pm 1.2$ seconds for mice fed with control, cooked, uncooked beans and serotonin precursor diets respectively. For day 3 of the acquisition training, the swim latencies was $18.20 \pm 1.9 ; 14.50 \pm 0.95 ; 14.20 \pm 1.2$ and $13.00 \pm$ 0.78 seconds for mice fed with control, cooked, uncooked, and serotonin precursor diets respectively. The swim latencies for the uncooked beans and serotonin precursor groups were significantly shorter than the control group during the 3 days of training $(\mathrm{p}<0.001)$. This is as shown in Figure 1.

\section{Reversal Training}

On day 1 , of the reversed training, the swimming latency for mice fed with normal, cooked, uncooked beans and serotonin precursor diets was $21.30 \pm 1.2 ; 18.30 \pm 2 ; 17.80 \pm 2.3$ and
$16.48 \pm 2.1$ seconds respectively. During the second day of reversal training, the swimming latency was $21.00 \pm 2.1 ; 18.10 \pm 2.3$; $17.00 \pm 1$ and $15.40 \pm 2.2$ seconds for mice fed normal, cooked, uncooked beans and serotonin precursor diet respectively. For day three (3) of the reversal training, the swimming latency was $21.40 \pm 2.3 ; 18.00 \pm 0.9 ; 17.20 \pm 1.7$ and $15.80 \pm 1$ seconds for mice fed with control, cooked, uncooked, and serotonin precursor diets respectively. The swim latencies for the cooked beans, uncooked beans and serotonin precursor groups were significantly lower during the reversal training (Figure 2) compared to the control $(p<0.001)$.

\section{Quadrant Duration During the Probe Trial Task (Re- tention Quadrant)}

Figure 3 compares the quadrant duration during the probe trial in the Morris water maze between the four experimental groups of mice. The duration of stay in each quadrant is shown in Figure 3. During the trial, the four groups had more preference 


\section{Anatomy Physiology \& biochemistry international journal (APBIJ)}

to the South-East quadrant (that bears the platform during the reversal training when compared to control).The preference to the SE quadrant for the mice fed with uncooked beans and serotonin precursor diet was significantly higher $(\mathrm{P}<0.05)$ compared

\section{Annulus Acquisition \& Annulus Reversal Crossings}

to control. However, the serotonin precursor and the uncooked beans group tends to have had more preference when compared to cooked beans group of mice.

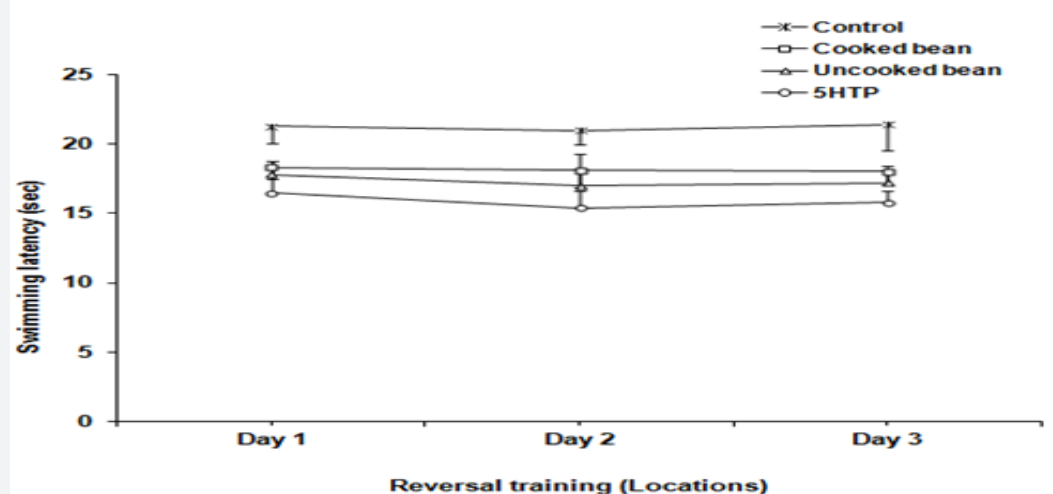

Figure 2: Swimming latency during reversal training among the different experimental groups recorded at days 4,5 and 6 in the Morris water maze test.

Values are expressed as mean $\pm \mathrm{SEM}, \mathrm{n}=10$.

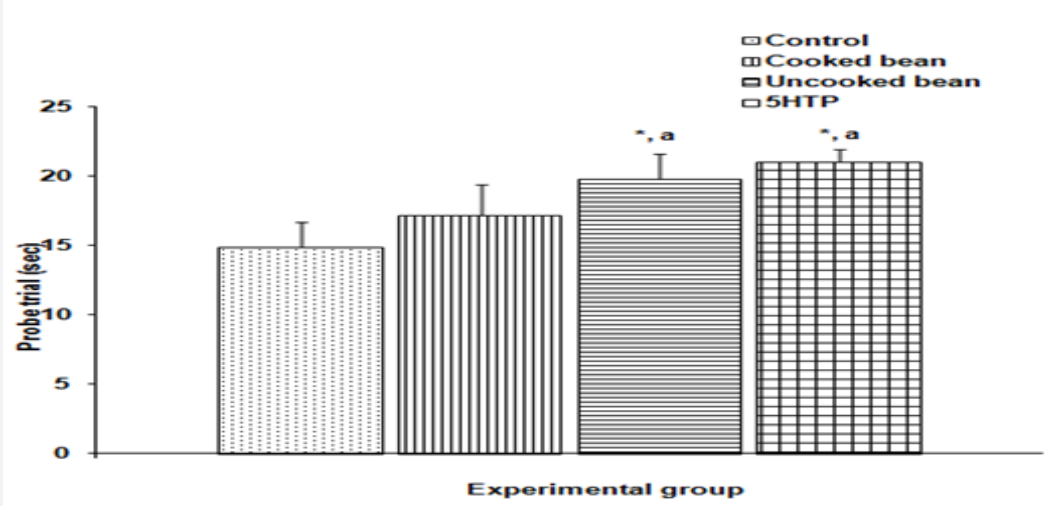

Figure 3: Retention quadrant during probe trials recorded at day 7 among south east the different experimental groups during the Morris water maze test.

Values are expressed as mean \pm SEM, $n=10$.

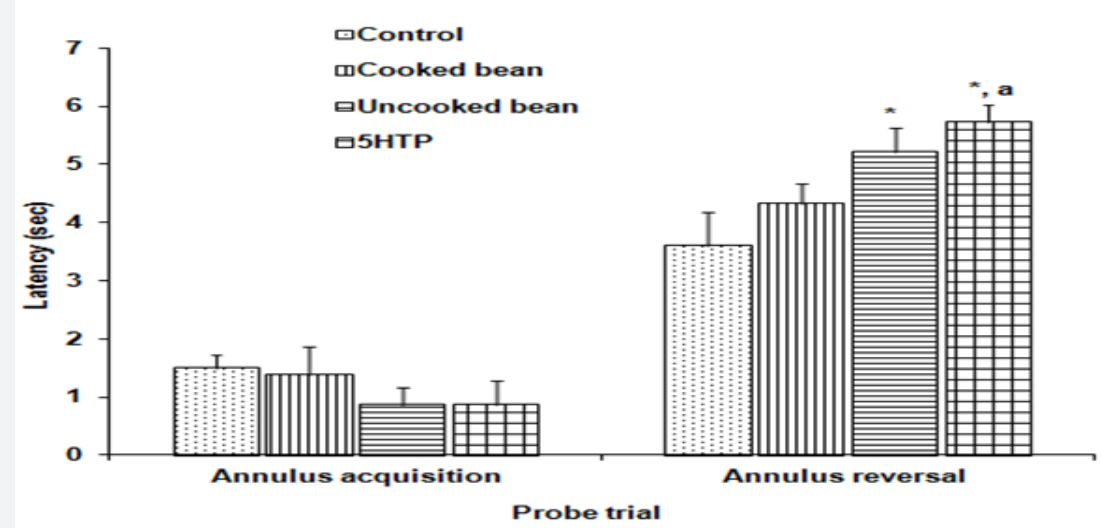

Figure 4: Annulus acquisition and reversal recorded at day 7 among the different experimental groups during the Morris water maze test on location south.

Values are expressed as mean \pm SEM, $n=10$. 


\section{Anatomy Physiology \& biochemistry international journal (APBIJ)}

Figure 4 compares the annulus acquisition and reversal crossings during the probe trial task. The values for the annulus acquisition crossings are $1.50 \pm 0.22 ; 1.38 \pm 0.50 ; 0.86 \pm 0.32$ and $0.86 \pm 0.43$ seconds for mice fed with normal, control, cooked, uncooked beans and serotonin precursor diets respectively. The values for the annulus reversal crossings are $3.60 \pm 0.58 ; 4.32$ $\pm 0.35 ; 5.21 \pm 0.43$ and $5.71 \pm 0.32$ seconds for mice fed normal, cooked, uncooked beans and serotonin precursor diets respectively. There was no significant difference among the groups in the annulus acquisition crossings. For the annulus reversal crossings, as shown in Figure 4, the uncooked beans and serotonin precursor fed mice was significantly higher compared to control $(\mathrm{P}<0.05)$. However, the serotonin precursor group was statistically higher $(\mathrm{P}<0.05)$ when compared to cooked beans group of mice.

\section{Visible Platform Task}

The swimming latency in the visual platform task was 25.59 $\pm 0.98 ; 22.09 \pm 1.33 ; 18.76 \pm 1.43$ and $17.98 \pm 1.20$ seconds for mice fed with normal, cooked, uncooked beans and serotonin precursor diets respectively. During visible platform task, the swim latencies of the cooked, uncooked beans and serotonin precursor group was significantly lower $(\mathrm{P}<0.05)$ compared to control. However, the serotonin precursor fed mice was significantly lower $(\mathrm{P}<0.05)$ when compared to cooked beans group of mice Figure 5.

\section{Discussion}

\section{Learning and Memory in the Water Morris Maze Task}
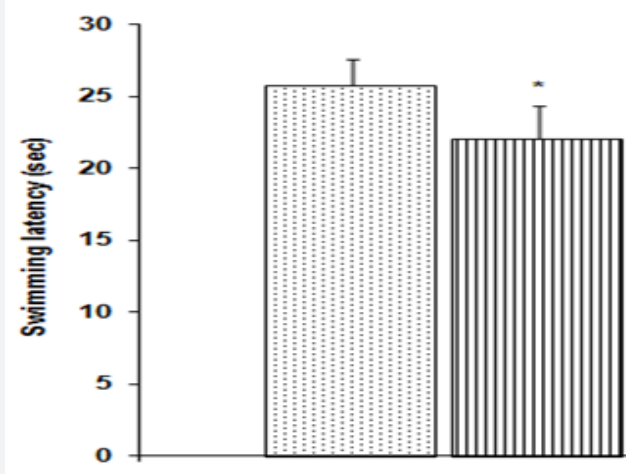

๑Control

mCooked bean

日Uncooked bean

Ф5HTP

Visible Platform

Figure 5: Visible platform among the different experimental groups recorded at day 8 in the Morris water maze test, values are expressed as mean $\pm \mathrm{SEM}, \mathrm{n}=10$.

No significant differences among groups

*significantly different from control at $p<0.05$

$a=$ significantly different from cooked bean at $p<0.05$

Learning simply refers to the ability to add knowledge to the brain while memory refers to the ability to remember what was learnt. The entire brain is involved in learning and memory. However, specialized learning requires specialized are of the brain. Therefore a substance that generally stimulates the central nervous system and increase alertness will improve learning and memory. The hidden platform version of Morris water maze is a test of visuo-spatial learning and memory. This process is impaired when the hippocampus is injured [16]. The visible (cued) platform uses a unique intra-maze visual cue that is placed at the location of the escape platform whereas the visuo-spatial learning task uses extra-maze cues. The swim latency was defined as the time it took the mice to locate the hidden platform in the visuo-spatial learning task or cued platform task. The shorter the swim latency the better the learning process. Mice that learn faster were able to identify the spatial location/position of the hidden platform earlier than their counter parts (within a short time). Also, the steeper the gradient of swim latencies within the three-days acquisition or reversal training, the better the learning curve, and thus learning.

The behaviors scored included swim latencies during acquisition, reversal training, visible platform task, and the quadrant duration during the probe trial. Following the consumption of cooked, uncooked beans and serotonin precursor diets, swim latencies for the first three days during acquisition training showed that the swim latencies of uncooked beans and serotonin precursor group were significantly lower compared to the control. During reversal training, the swim latencies for the three days in the mice that consumed cooked, uncooked beans and serotonin precursor diets were all shorter than the control group. This means that these groups of mice were able to locate the hidden platform faster and so, learned faster than the control group of mice that consumed normal rodent chow. Also, the gradient of curve of the swim latencies indicates that the cooked, uncooked beans and serotonin precursor fed mice learnt faster 


\section{Anatomy Physiology \& biochemistry international journal (APBIJ)}

than the control. Visuo-spatial memory was assessed during the probe trial in the Morris water maze task.

During the probe trial(60 seconds exploration without hidden platform), it is expected that mice which had a good memory of the spatial location/position of the hidden platform would spend more time exploring the quadrant which had the platform during reversal training, in this case, the retention quadrant was South-East(SE) quadrant. Mice that consumed uncooked beans and serotonin precursor diet spent significantly more time than the control exploring the retention quadrant. This showed that they had better memory than the control group of mice that consumed normal rodent chow. Also, the result suggests that the uncooked beans group of mice may have better memory than the cooked beans group of mice as the retention quadrant is significantly higher in the uncooked beans group than in the cooked beans group.

The cued version of the Morris water maze assesses cued learning and visual integrity of the animals tested. Impairments in performance in the hidden platform model may be due to some brain lesions or drugs which may affect the motivation to escape, or sensory motor factors rather than spatial learning. This cueing procedure, in which the escape platform protrudes above the water surface, provides a control for this [17]. here, the swim latencies were also used for the comparisons. Shorter swim latencies in the visible platform task indicate improved cued learning. Longer swim latencies indicate poor cued learning. The mice that consumed both beans (cooked and uncooked) diets and serotonin precursor diet had significantly lower swim latencies compared to the mice that consumed normal rodent chow. This means that beans consumption (cooked and uncooked) improved learning process and visual integrity in mice. Beans are rich in vitamin B6 and contain serotonin (5HT) as well as its precursor 5-Hydroxytryptophan (5-HTP) and tryptophan [9] in significant measures. Tryptophan hydroxylase converts tryptophan into 5-HTP which in turn is converted into serotonin (5-HT) by the enzyme aromatic amino acid decarboxylase that uses vitamin B6 as co-enzyme. Serotonin is a neurotransmitter that is known to improve learning and memory as well as cognitive functions [18]. Therefore, our studies showed that beans diet improve both hippocampus and non-hippocampus-dependent learning and memory.

\section{Conclusion}

Nigerian beans (Cowpea) enhance both hippocampus and non-hippocampus dependent learning and memory in mice. If these results are applicable to man, consumption of beans diet could be beneficial in improving learning and memory in humans. However, the potential unexpected effects of beans consumption must be kept in mind.

\section{References}

1. Gatel F (1994) Quality of legume seeds for Non-Ruminant Animals. Animal Feed Science and Technology 45(3): 317-348.

2. Wortman CS (2006) Phaseolus vulgaris (Common beans). Record from PROTAAU. In: Brink M \& Basey G (Eds.), PROTA (Plant Resources of Tropical Africa) Netherlands, Europe.

3. Wader JKP, Telek L, Vozari Hampem, Sami HS (1998) Antinutritional factors in Anasazi and other pinto beans (Phaseolus vulgaris). Plant Foods for Human Nutrition 51(2): 85-98.

4. Adeyele EJ (1995) Studies of Chemical Composition and functional properties of African Yam beans (Spensotylis Stenoorpa) flour Ph.D Thesis, Department of chemistry, Federal University of Technology, Akure, Ondo State, Nigeria.

5. Shansudden AM, Elsayed A (1998) Suppression of large intestinal Cancer in F344 rats by Inositol Hexaphosphate. Carcinogenesis 9(4): 577-580.

6. Vander Poel AFB, Mollee PW, Huisman J, Liner IE (1990b) Variations among species of animals in response to the feeding of heat-processed beans. Bean processing and effects on growth digestibility and organ weights in piglets. Livestock Production Science 25(1-2): 121-135.

7. Gref E, Eaton JW (1993) Suppression of Caloric Cancer by Dietary Phytic Acid. Nutr Cancer 19(1): 11-19.

8. Bennick E, Maurice O, Elizabeth R (2008) Beans \& Health: A comprehensive Review. Frazee, MN, USA.

9. Portas CM, Bjorvatn B, Ursin R (2000) Progress in Neurobiology. International Review Journal 60(1): 13-35.

10. Brunton LB, Lazio JS, Parker KL (2005) The Pharmacological Basis of Therapeutics. New York, USA, 64(8): 607-629.

11. Daniel LC, Michael RK (2007) Biogenic amine neurotransmitters in C elegans, Worm Book, Panadesa. The Online Review of C. elegans Biology p. 1-15.

12. Messman T (2005) Psychiatric drugs: Chemical warfare on humans: Interview with Robert Whitaker, Mind Freedom, Ireland.

13. Feldman JM, Lee E (1985) Serotonin content of foods: Effect on urinary excretion of 5-hydroxylindole acetic acid. Am J Clin Nutr 42(4): 639643.

14. Mosienko V, Bert B, Beis D, Mather S, Fink H, et al. (2012) Exaggerated aggression and decreased anxiety in mice deficient in brain serotonin. Transl Psychiatry 2: e122.

15. Paylor R, Baskall Baldini L, Yuva L, Wehner JM (1996) Developmental differences in place-learning performance between C57BL/6 and DBA/2 mice parallel the ontogeny of hippocampal protein kinase C. Behav Neurosci 110(6): 1415-1425.

16. Mcdonald RJ, White NM (1994) Parallel information processing in water maze: Evidence for independent memory systems involving dorsal striatum and hippocampus. Behav Neural Biol 61(3): 260-270.

17. Morris R (1984) Developments of a water-maze procedure for studying spatial learning in the rat. J Neurosci Methods 11(1): 47-60.

18. Walther DJ, Peter JU, Winter S, Holtz M, Paulmann N, et al. (2003) Serotonylation of small GTPases is a signal transduction pathway that triggers platelet alpha-granules release. Cell 115(7): 851-862. 
Your next submission with Juniper Publishers will reach you the below assets

- Quality Editorial service

- Swift Peer Review

- Reprints availability

- E-prints Service

- Manuscript Podcast for convenient understanding

- Global attainment for your research

- Manuscript accessibility in different formats ( Pdf, E-pub, Full Text, Audio)

- Unceasing customer service

Track the below URL for one-step submission https://juniperpublishers.com/online-submission.php 